\title{
Penyakit Ternak yang Perlu Diwaspadai Terkait Keamanan Pangan
}

\section{Livestock Disease that Needs to be Watched OutRelated to Food Safety}

\author{
Wiwik Heny Winarsih \\ Badan Penelitian dan Pengembangan Provinsi Jawa Timur
}

DOI: https://doi.org/10.32781/cakrawala.v12i2.270

\begin{tabular}{l}
\hline ARTICLE INFO \\
Penyakit Ternak, \\
Produktivitas, \\
Keamanan Pangan, \\
Livestock Diseases, \\
Productivity, \\
Food Safety
\end{tabular}

Article History:

Received : Oktober 2018

Accepted : December 2018
Abstrak:

Tujuan kajian ini adalah: (1) jenis penyakit ternakdan patologi yang terjadi di Jawa Timur; (2) menemukan cara mencegah dan menanggulangi berbagai penyakit agar produksi pangan asal ternak tidak terganggu dan aman dikonsumsi. Metode kajian bersifat deskriptif dengan mencermati data-data sekunder, kejadian terkini terkait penyakit ternak dan kemanan pangan asal ternak. Kesimpulan: (1) Dari 25 jenis penyakit hewan menular strategis yang teridentifikasi, terdapat beberapa jenis diantaranya yang dapat menimbulkan bahaya bagi kesehatan manusia yang terpapar baik melalui kontak langsung dengan penderita, melalui makanan yang dikonsumsi, atau melalui udara yang terhirup dan/atau kontak langsung dengan hewan yang sakit, terinfeksi atau mati. Selama kurun waktu 2016-2017 dilaporkan terdapat limajenis kejadian PHMS; yaitu antraks, brucellosis, IBR, leptospirosis, dan paratubercullosis; dan dua jenis kejadian penyakit parasiter. Selain itu terdapat residu dua jenis obat golongan Tetracyclin pada daging sapi dan Aminoglikosida pada daging ayam; (2) Cara mencegah dan menanggulangi berbagai penyakit agar produksi pangan asal ternak aman dikonsumsi adalah senantiasa menggunakan bibit unggul bersertifikat (kalau ada) serta menerapkan cara beternak yang baik, menggukan pakan yang sehat, dan menerapkan biosekuriti secara ketat agar produknya aman dikonsumsi.

Abstract:

The objectives of this study are: (1) the types of livestock diseases and pathologies that occur in East Java; (2) find ways to prevent and overcome various diseases so that food production from livestock is not disturbed and safe for consumption. The study method is descriptive by looking at secondary data, current events related to livestock disease and food safety from livestock. Conclusion: (1) Of the 25 types of strategic infectious animal diseases identified, there are several types of which can pose a danger to human health that is exposed either through direct contact with patients, through food consumed, or through inhaled air and / or direct contact with sick animals, infected or dead. During the period of 2016-2017 it was reported that there were five types of PHMS diseases; namely anthrax, brucellosis, IBR, leptospirosis, and paratubercullosis; and two types of parasitic diseases. In addition there are residues of two types of Tetracyclin drugs in beef and Aminoglycosides in chicken meat.(2) The way to prevent and overcome various diseases so that food production from livestock is not disturbed is to always use certified superior seeds (if any) and apply good breeding methods, use healthy feed, and strictly apply biosecurity so that the products are safe for consumption.

Cite this as:

Winarsih, W. H. (2018). Penyakit Ternak yang Perlu Diwaspadai Terkait Keamanan Pangan. Cakrawala, 12(2). 208-221. https://doi. org/10.32781/cakrawala.v12i2.270

${ }^{\square}$ Corresponding author :

Address : Jl. GayungKebonsari 56, Surabaya

Email : whwinarsih@yahoo.com

Phone
(C) 2018 Badan Penelitian dan Pengembangan Provinsi Jawa Timur p-ISSN 1978-0354 | e-ISSN 2622-013X 


\section{Pendahuluan}

Penyakit ternak (hewan) adalah gangguan kesehatan pada hewan ternak yang disebabkan oleh cacat genetik, proses degeneratif, gangguan metabolisme, trauma, keracunan, infestasi parasit, prion, dan infeksi mikroorganisme patogen (Undang-Undang Nomor 41 Tahun 2014). Di antara berbagai jenis penyakit tersebut yang paling berbahaya adalah parasit, prion, dan mikroorganisme patogen yang bisa berpindah atau menular pada manusia. Begitu luas dan beragamnya jenis penyakit pada hewan ternak maka diperlukan pemahaman dalam mengenali gejala-gejala penyakit yang mungkin terjadi (mengiringi symptom) agar dapat dilakukan pengendalian dan pengobatan secara seksama. Kewaspadaan terhadap terjadinya suatu penyakit perlu dilakukan sepanjang proses produksi dan budidaya peternakan. Provinsi Jawa Timur sebagai gudang ternak memiliki kewajiban untuk menjaga agar produk ternak yang dihasilkan menjamin produk yang Aman, Sehat, Utuh, dan Halal (ASUH).

Tujuan utama usaha peternakan adalah menghasilkan bahan pangan sumber protein bergizi tinggi berupa daging, susu, dan telur.Seluruh rangkaian proses produksi sejak on farm sampai off farm lalu ke meja makan harus ada jaminan aman dikonsumsi. Pepatah lama lebih baik mencegah daripada mengobati sangat relevan diterapkan pada usaha peternakan. Penyakit hewan ternak dikelompokkan menjadi penyakit menular dan penyakit menular strategis. Penyakit hewan menular adalah penyakit yang ditularkan antara hewan dan hewan, hewan dan manusia, serta hewan dan media pembawa penyakit hewan lain melalui kontak langsung atau tidak langsung dengan media perantara mekanis seperti air, udara, tanah, pakan, peralatan, dan manusia; atau melalui media perantara biologis seperti virus, bakteri, amuba, atau jamur. Penyakit hewan menular strategis adalah penyakit hewan yang dapat menimbulkan angka kematian dan/atau angka kesakitan yang tinggi pada hewan ternak, dampak kerugian ekonomi, keresahan masyarakat, dan/atau bersifat zoonotik. Zoonosis adalah penyakit yang dapat menular dari hewan kepada manusia atau sebaliknya.

Keamanan pangan adalah kondisi dan upaya yang diperlukan untuk mencegah pangan dari kemungkinan cemaran biologis, kimia, dan benda lain yang dapat menggangu, merugikan, dan membahayakan kesehatan manusia serta tidak bertentangan dengan agama, keyakinan, dan budaya masyarakat sehingga aman untuk dikonsumsi (Undang-Undang Nomor 18 Tahun 2012). Bahaya yang berkaitan dengan keamanan pangan asal ternak dapat terjadi pada setiap mata rantai mulai dari kandang, pasar, rumah potong, dapur, sampai meja makan. Pada saat di kandang jaminan keamanan dikelola oleh peternak, selama dalam proses distribusi ditangani oleh pengelola jasa pengiriman, selama dalam proses pemotongan dikelola Rumah Potong Hewan (RPH) dan atau Rumah Potong Unggas (RPU). Saat ini pengusahaan daging, susu, dan telur dilakukan oleh masyarakat secara mandiri dan/atau berkelompok, serta perusahaan peternakan. Terkait dengan sistem manajemen keamanan pangan, Badan Standarisasi Nasional (BSN) telah menyusun Persyaratan untuk Organisasi Dalam Rantai Pangan dalam SNI ISO 22000:2009.

Pembangunan peternakan yang tangguh merupakan tanggung jawab bersama antara pemerintah, masyarakat peternak, dan pengusaha. Masyarakat dan pengusaha peternakanmemilikikesempatan luas untuk mengembangkan usaha dalam rangka memenuhi kebutuhan protein hewani dari segi produksi, pengolahan, perdagangan, distribusi sampai importasi sepanjang diperlukan dan mendapatkan 
ijin resmi dari pemerintah. Rumusan masalahnya adalah: (1) Jenis penyakit ternak apa yang potensial menyerang ternak di jawa Timur?; (2) Bagaimana cara mencegah dan menanggulangi berbagai penyakit agar produksi pangan asal ternak tidak terganggu? Tujuan penelitian ini adalah: (1) Mengkaji jenis penyakit ternakdan patologi yang terjadi di Tawa Timur; (2) Menemukan cara mencegah dan menanggulangi berbagai penyakit agar produksi pangan asal ternak tidak terganggu.Selama ini bukti empiris menunjukkan terjadinya suatu penyakit dipicu perubahan cuaca dari musim kemarau ke musim penghujan. Perubahan cuaca biasanya diikuti dengan fluktuasi suhu dan kelembaban di suatu daerah; berdampak pada kesehatan dan produktivitas hewan ternak.

\section{Tinjauan Pustaka}

\section{Jenis Penyakit Ternak Yang Bebahaya}

Jenis penyakit ternak yang berbahaya perlu diwaspadai agar tidak menjangkiti ternak yang dibudidayakan; sehingga seluruh rangkaian produksi perlu dilakukan dengan menerapkan prosedur cara beternak yang baik. Impor ternak dalam bentuk bakalan atau induk juga harus cermat agar tidak membawa agen penyakit berbahaya dari negara asal. Peran karantina sangat penting dalam rangka screening agar semua produk bahan pangan yang masuk terbebas dari penyakit dan cemaran biologis yang bisa membahayakan konsumen. Keamanan pangan asal ternak diperlukan dalam rangka penguatan daya saing di era perdagangan bebas sebagaimana diamanatkan dalam perundingan putaran Uruguai tahun 1994. Hasil perundingan yang diikuti 125 negara anggota WTO ini berdampak luas mencakup kesepakatan dan keputusan mengenai perdagangan internasional berupa General Agreement on tarif Tarif and Trade (GATT). Dalam keputusan tersebut dicapai juga kesepakatan aplikasi tindakan sanitary and phytosanitary yang mengatur tindakan perlindungan keamanan pangan dalam bidang kesehatan hewan dan tumbuhan yang perlu dijalankan oleh negara-negara anggota WTO termasuk Indonesia. Tujuannya adalah melindungi kehidupan manusia dari risiko yang ditimbulkan oleh bahan makanan tambahan (additives), cemaran (contaminant), racun (toxins) atau organisme penyebab penyakit dalam makanan atau dari penyakit zoonosis (Bahri dkk, 2002).

Bahan pangan asal ternak sebagai sumber protein hewani yang sangat penting berupa daging, susu, dan telur. Daging asal ternak diperoleh dari aneka unggas, ruminansia, dan ternak lain; susu diperoleh dari ternak ruminansia besar terutama sapi dan ruminansia kecil terutama kambing; telur diperoleh dari aneka unggas. Daging asal unggas disumbangkan paling banyak oleh ayam broiler, ayam kampung, itik, ayam petelur afkir, entog, kalkun, angsa, burung puyuh afkir, dan burung dara. Total sumbangan daging asal unggas mencapai 60,8\% (Ditjenak, 2006 dalam Talib dkk, 2007).

Dalam rangka menjamin produk pangan yang aman dan sehat untuk dikonsumsi oleh masyarakat, Pemerintah Indonesia telah melengkapi berbagai perangkat perundang-undangan, peraturan pemerintah, sarana laboratorium pengujian, standar nasional untuk pangan asal ternak, program monitoring dan surveilans serta sistem jaminan keamanan pangan produk peternakan. Bahaya atau hazard yang berkaitan dengan keamanan pangan asal ternak dapat terjadi pada setiap mata rantai produksi pangan. Bahaya yang berkaitan dengan keamanan pangan asal ternak dikelompokkan menjadi empat (4) bagian (Bahri, Sani, dan Indraningsih, 2006); yaitu: (1) Penyakit ternak (zoonosis); (2) Penyakit bawaan makanan (food borne disease); (3) Cemaran atau kontaminasi; (4) Pemalsuan dan bahan pengawet. Selain 
itu, ada dampak bencana ikutan yang dapat menyebabkan ternak sakit yaitu banjir. Berikut beberapa jenis penyakit pada ternak yang dapat ditularkan pada manusia dan/ atau yang daging dan susunya tidak boleh dikonsumsi; yaitu:

\section{Penyakit Bovine Spongiform Encepha- lopathy (BSE) atau Sapi Gila}

Penyakit Bovine Spongiform

Encephalopathy (BSE) atau sapi gila (mad cow) pertama kali dilaporkan terjadi di Inggris pada Nopember 1986. Kasusnya sangat banyak, diidentifikasi sebanyak 170.000 kasus dan bersifat menular. Kejadian sporadis terjadi disejumlah negara Eropa seperti Belgia, Perancis, Italia, Portugal, dan Spanyol. Penyakit sapi gila ditularkan kepada manusia melalui konsumsi daging sapi yang terinfeksi; atau berkontak dengan sapi-sapi yang terjangkit penyakit sapi gila.

Penyakit sapi gila menyerang jaringan saraf otak manusia dalam bentuk new varian Creutzfeldt Jakob Disease (nvCJD) atau Alzheimer Disease (AD) dan bersifat degeneratif. Manusia yang terkena CJD akan kehilangan kekuatan, pertumbuhan terhenti, lambat laun sel otak menjadi tidak utuh dan berubah menjadi seperti spons. Belum ada vaksin sampai kini (Nugraheni, 2013) sehingga upaya pencegahan sangat perlu dilakukan. Yang terpenting mencegah masuknya bibit sapi yang berasal dari negara-negara yang pernah terjangkiti sapi gila; serta mencegah masuknya, daging, dan produk daging yang kemungkinan tertular penyakit sapi gila. Pemerintah Indonesia harus ekstra waspada dan menerapkan sistem karantina yang sangat ketat agar segala bentuk penyakit sapi yang membahayakan peternakan dan masyarakat Indonesia dapat dicegah. Direktur Jenderal Peternakan Dan Kesehatan Hewan pada tanggal 4 Januari 2012 berkirim surat kepada Kepala Dinas Peternakan Seluruh Propinsi tentang Pelarangan Penggunaan Bahan Pakan asal Ruminansia (MBM) untuk pakan ternak Ruminansia.Penyakit ini memiliki implikasi sosio ekonomis atau kesehatan masyarakat, terutama dalam perdagangan hewan dunia. Penyakit nvCJD pada manusia mampu menularkan secara horisontal melalui transplantasi atau oral dan bersifat genetik. Mengkonsumsi daging sapi, kambing, dan domba BSE, serta material yang memiliki risiko spesifik sangat berisiko tinggi tertular. Jika manusia sudah terkena nvCJD, maka tidak ada lagi kekebalan tubuh dan masa inkubasinya 2-10 tahun.

Penyakit sapi gila diduga berawal dari perubahan pola hidup manusia dan hewan. Secara alami, pakan utama sapi adalah rumput. Namun agar sapi tumbuh cepat diberi pakan tepung tulang dan daging. Penyakit mad cowÂ berawal dari pemberian pakan sapi asal tepung tulang dan daging domba yang terjangkit BSE. Kemudian manusia makan daging sapi yang tercemar BSE, sehingga manusia pun terjangkit nvCJD (Sumber Berita: http:// dinakkeswan.jatengprov.go.id). Tepung daging dan tulang ini di dunia peternakan dikenal sebagai Meat and Bone Meal (MBM). Bahaya penggunaan MBM pada ternak diantaranya adalah:

a. Praktek pencampuran pakan unggas dan babi dalam pakan ruminansia dapat mengakibatkan terjadinya penyakit BSE/Madcow/Sapi Gila pada sapi dan membahayakan kesehatan manusia.

b. BSE adalah penyakit pada sapi yang menyerang susunan syaraf pusat dengan ditandai adanya Spongious atau terbentuknya lubang kosong pada sel otak yang berdampak fatal (fatal neurological disease).

c. BSE disebabkan oleh Protein Prion (PrP) yang berasal dari MBM.

d. Prion adalah sejenis protein yang abnormal yang memiliki sifat : mempunyai kemampuan merusak 
protein lain, tidak dapat dihancurkan dengan disinfektan, bahan kimia maupun suhu tinggi.

e. Prion terdapat dalam otak, sumsum tulang belakang dan tonsil sapi berumur lebih 30 bulan dan tidak rusak dalam pengolahan dengan pemanasan biasa. Cara penularan prion terutama terjadi melalui pakan yang terkontaminasi oleh MBM yang berasal dari hewan penderita. Yang dapat tertular adalah: hewan ruminansia (sapi, kambing, domba), karnivora (kucing rumah, harimau) dan primata terutama monyet (Sumber: http://dinakkeswan. jatengprov.go.id)

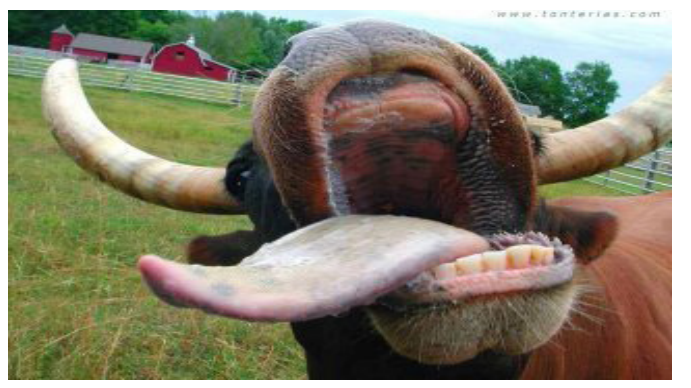

Gambar 1

Penyakit Sapi Gila yang Membahayakan Manusia

Sumber: https://www.google.co.id/search?q= gambar+penyakit+sapi+gila

\section{Penyakit Mulut dan Kuku (PMK)}

Penyakit mulut dan kuku (PMK) menjangkiti sapi, kerbau, kambing, domba, babi, dan jenis-jenis hewan sebangsanya. Penyebab PMK adalah Aphtae epizootica. Ada tujuh tipe virus PMK, yaitu: A, O, C, Asia, South African Teritory (SAT) 1, 2, dan 3. Setiap tipe virus PMK masih terbagi lagi menjadi beberapa sub tipe dan galur. Sejauh ini di Indonesia hanya ada satu tipe virus $\mathrm{PMK}$, yaitu virus tipe $\mathrm{O}$ yang menyerang mulut dan kuku. PMK bersifat zoonosis sehingga bisa menular pada manusia. Penularan virus PMK umumnya terjadi secara kontak dalam kelompok hewan atau proses lewat makanan, minuman, atau alat yang tercemar virus. Hewan ternak yang tertular mengeluarkan virus dalam jumlah sangat banyak lewat ekskreta (feses dan urine), terutama air liur. Gejala awal muncul demam yang sangat cepat diikuti munculnya lepuh atau vesikula pada lidah dan daerah interdigit (celah kuku). Lepuh lidah pecah kemudian terjadi hipersalivasi berwarna bening menggantung pada bibir. Pada saat demikian sapi tidak mau makan dan akhirnya kurus drastis. Lepuh juga dapat terjadi pada puting dan kelenjar mamae (Rianto dan Purbowati, 2010).

Tahun 2017 terdapat lebih dari 100 negara di dunia yang masih tertular PMK dan hanya sedikit negara yang memiliki zona bebas PMK. Kondisi tersebut menyeret Hakim Mahkamah Konstitusi terjerat kasus suap dalam memuluskan uji materi UU Nomor 41 Tahun 2014 tentang Peternakan dan Kesehatan Hewan; agar keputusannya hanya memperbolehkan impor ternak sapi dan daging sapi dari negara yang bebas penyakit PMK, bukan dari negara yang bebas PMK berdasarjan zona. Hal tersebut bisa menjadi non trade barriers agar Indonesia hanya mengimpor sapi dan daging dari Australia dan/atau New Zealand. Tanpa kompetitor maka harga daging impor asal Australia akan tetap tinggi (Daryanto, 2017). Disisi lain Pemerintah menginginkan daging sapi yang harganya terjangkau Rp80.000,- per kilogram.

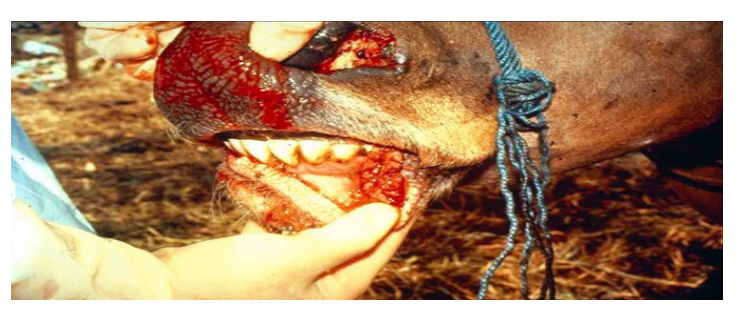

\section{Gambar 2}

Penyakit Mulut dan Kuku pada Sapi

Sumber: https://www.google.co.id/search?q=g ambar+penyakit + mulut + dan + kuku 


\section{Penyakit Tuberculosis (Tb)}

Penyakit tuberculosis $(\mathrm{Tb})$ pada berbagai jenis hewan termasuk sapi disebabkan oleh kuman Mycobacterium tuberculose, atau Mycobacterium bovus. Kuman Tb di alam ada tiga tipe, yaitu human, bovine, dan avian. Tb menyerang saluran pernafasan, terutama paru-paru dan pleura; hewan yang terserang tampak kurus. Organ tubuh yang terserang $\mathrm{Tb}$ disarankan tidak dikonsumsi. Kuman TB dapat mencemari susu sehingga jika sapi sudah terduga dan terdiagnosis TB maka susunya tidak boleh dikonsumsi. TB dapat menular melalui ekskresi,sputum (dahak), feses, susu, urin, semen, traktus genitalis (saluran kelamin), pernapasan, ingesti, dan perkawinan dengan hewan yang sakit (Rianto dan Purbowati, 2010). Pencegahan sangat perlu dilakukan dengan penerapan sanitasi kandang dan lingkungan yang baik.

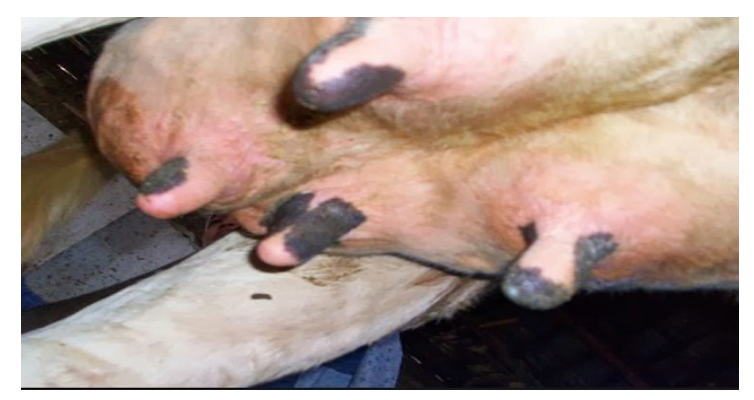

\section{Gambar 3}

Penyakit Tuberculosis pada Sapi Perah, Ambing Menghitam Tidak Normal

Sumber: https://www.google.co.id/search ?q=gambar + penyakit + tuberculosis + pada + ternak

\section{Penyakit Antraks}

Penyakit antraks memiliki beberapa istilah, yaitu: radang kura, radang limpa, malignant pustula, malignant edema, woolsoster's disease, ragpickers disease, splenic fever, charbon, atau caneung hideung; disebabkan olehBacillus anthraxis. Bakteri ini dapat hidup bertahun-tahun dalam bentuk spora. Jika keadaan memungkinkan, spora akan aktif kembali. Anthraks dapat menyerang sapi, kerbau, kambing, domba, kuda, babi, burung unta, serta hewan lain seperi tikus, marmut, dan mencit. Lingkungan yang tercemar Bacillus anthraxis seperti tanah, tanaman sayur dan rerumputan, air juga dapat menjadi sumber penularan. Sapi yang terserang antraks sering mati mendadak. Gejala yang timbul pada ternak adalah suhu tubuh tinggi, kejang, leher bengkak, terjadi pendarahan pada telinga, hidung, anus, vagina; hilang nafsu makan, dan lemah otot. Pencegahan yang bisa dilakukan agar tidak terserang antraks adalah melakukan vaksinasi secara teratur.Jika ternak mati karena anthrax harus dikubur dengan kedalaman minimal dua meter. Jika sapi terserang anthrax harusdikarantina dan sesegera mungkin mengobatinya dengan penicillin berdosis tinggi (Rianto dan Purbowati, 2010). Di Indonesia, anthrax pertama kali dilaporkan tahun 1832 di Kabupaten Kolaka Sulawesi Tenggara dan setelah itu mulai diberitakan kejadian anthrax di beberapa wilayah yang lain (Murwani dkk, 2017). Manusia yang tertular penyakit antraks secara langsung atau tidak langsung terpapar oleh produk hewan yang terkontaminasi seperti daging, kulit binatang, tulang, dan bahan lain dari hewan ternak yang terinfeksi (Gombe et al 2010 dalam Martindah, 2017).

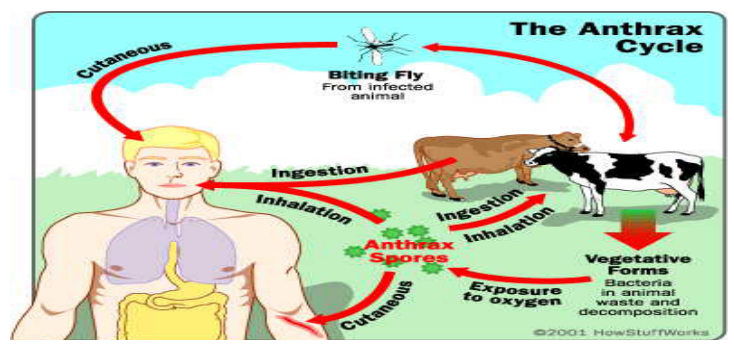

\section{Gambar 4}

Siklus Antraks pada Ternak yang Menjangkiti Manusia

Sumber: http://www.infonajwa.com/wpcontent/uploads/2013/10/penyakit-antraks.jpg) 


\section{Penyakit Brucellosis (Jawa: kluron} menular)

Penyakit Brucellosis disebabkan oleh bakteri Brucella abortus Bang, bersifat zoonosis; artinya penyakit tersebut menular dari hewan ke manusia. Sapi yang terjangkit brucellosis susunya tidak boleh diminum karena bisa menyebabkan demam. Penularan melalui kontak langsung, melalui serangga, melalui luka, perkawinan alami, kawin suntik, melalui pakan, air minum, atau peralatan kandang yang tercemar (Bakri dan Saparinto, 2015); dan eksudat alat kelamin, selaput lendir mata. Sapi bunting yang terkena brucellosis akan mengalami abortus pada 6-9 bulan kebuntingan. Aborsi bisa terjadi satu, dua, atau tiga kali. Gejala klinis yang tampak antara lain selaput fetus yang diaborsikan terlihat oedema, hemorhagi, nekrotik, adanya eksudat kental, retensi placenta, mastitis, dan keluar kotoran dari vagina (Rianto dan Purbowati, 2010).

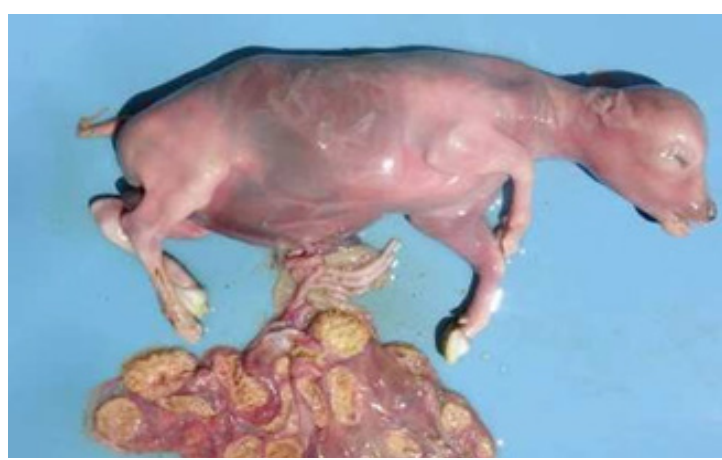

\section{Gambar 5}

Fetus yang Diaborsikan karena Induk Terkena Penyakit Brucellosis

Sumber: https://Www.Google.Co.Id/Search?Q $=$ Gambar + Penyakit + Brucellosis

\section{Penyakit Radang Paha (blackleg)}

Penyakit radang paha disebabkan oleh bakteri anaerob gram positif berspora Clostridium chauvoei yang biasanya menyerang sapi atau domba. Menurut sejarah, radang paha pertama kali ditemukan di Indonesia tahun 1891 di
Tegal; dua dekade berikutnya dilaporkan terjadi di Tuban dan menyebar ke Blora, Yogyakarta, Surakarta, Semarang, dan Madiun(Vletter 1907 dalam Natalia, 2000). Penyakit bersifat akut dengan gejala klinis pembengkakan pada jaringan sub kutan terutama bagian bahu dan paha yang jika ditekan terasa seperti ada gas atau udara yang berpindah-pindah. Otot berwarna merah kehitaman dan oedematous pada daerah yang membengkak dengan tempat udara di bagian tengah. Karkas hewan penderita radang paha tidak boleh dikonsumsi dan tidak boleh diperdagangkan (Bahri dkk, 2002).

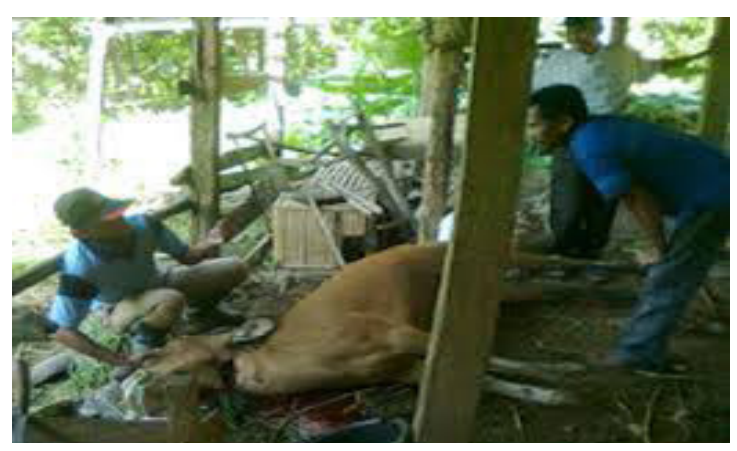

Sumber: https://www.google.co.id/search?q=g ambar+penyakit+radang + paha

\section{Gambar 6}

Sapi Mati Mendadak Terserang Radang Paha

\section{Penyakit Avian Influenza}

Penyakit avian influenza (AI) atau flu burung menyerang ayam, itik, entog dan angsa; yang oleh masyarakat peternak dinamakan penyakit mata biru. Sumber virus diduga berasal dari migrasi burung dan transportasi unggas yang terinfeksi. Di Indonesia, pada Januari 2004 dilaporkan kasus kematian ayam yang luar biasa terjadi di Bali, Jawa Timur, Jawa Tengah, Jawa Barat, Kalimantan Barat dan kawasan Bogor, Tangerang, Bekasi. Penyakit AI bersifat sangat ganas dan menyebabkan kematian massal dalam waktu relatif singkat. Kini kejadian AI dilaporkan 
menurun. Keberhasilan pengendalian AI didukung komunikasi yang baik antara peterak dan Instansi terkait baik di pusat maupun di daerah. Secara nasional jika ada kejadian AI dapat dilaporkan melalui SMS ke Tim Respon Cepat setempat/ daerah terdekat atau melalui SMS dan Call Center AI Direktorat Kesehatan Hewan No.08118301001 atau melalui Pelapor Desa (PELSA) untuk diteruskan melalui iSIKHNAS. Dan informasi kejadian AI pada unggas terkini di Indonesia dapat diakses melalui website: www. keswan.dirjenpkh.pertanian.go.id(Kolom Berita, Judul Laporan Perkembangan AI di Indonesia) (http://ditjennak.pertanian. go.id/situasi-kejadian-avian-influenza-aipada-unggas-kondisi-s-d-31-maret-2017).

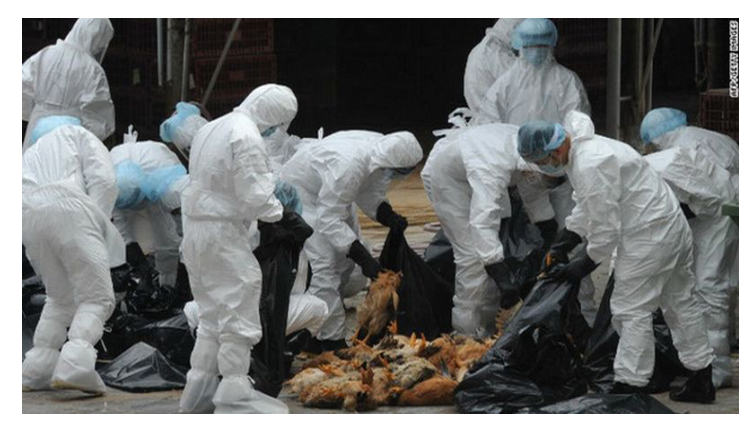

\section{Gambar 7}

Serangan AI pada Unggas Menyebabkan Kematian Massal

Sumber: https://www.google.co.id/search? $\mathrm{q}=$ gambar + penyakit $+\mathrm{AI}+\mathrm{di}+$ indonesia

\section{Hasil dan Pembahasan}

Penyakit ternak yang paling ditakutkan oleh sebagian besar masyarakat adalah antraks, brucellosis, dan avian influenza (AI). Masyarakat peternak unggas mengenal AI sebagai penyakit mata biru. AI pada unggas danantraks pada sapi merupakan penyakit yang paling ditakuti. Balai Besar Veteriner Wates Yogyakarta yang wilayah kerjanya meliputi Jawa Tengah, Yogyakarta, dan Jawa Timur mendapati daerah yang merupakan endemis antraks di Jawa Timur adalah Kabupaten Pacitan, Kabupaten
Blitar, dan Kota Blitar (Ruhiat dkk, 2018). Antraks menyerang seluruh tubuh (septicemia) dan seringkali menyebabkan kematian mendadak. Gejala kunci terjadi penggembungan badan dan keluarnya cairan darah berwarna kehitaman dari lubang rectum, hidung, mulut, dan bukaan lainnya.

Penyebab antraks adalah Bacillus anthracis yang jika terkena udara bebas akan membentuk spora yang disebut basilus antraks dan mampu hidup di dalam tanah selama 60 tahun (Blakely dan Bade, 1992). Kasus antraks seringkali muncul pada awal musim hujan dimana rumput sedang tumbuh yang menyebabkan terjadinya kontak dengan spora yang ada di dalam tanah. Ternak yang merumput menjadi terinfeksi apabila memakan spora dalam jumlah infektif. Infeksi secara langsung dapat terjadi melalui gigitan lalat yang secara mekanik menyebarkan spora Bacillus anthracis dari hewan ke hewan lainnya. Makan makanan yang berasal dari tulang atau daging mentah yang tidak dimasak dengan tepat juga menjadi sumber penularan pada manusia (Murwani dkk, 2017). Umumnya antraks menyerang sapi, kerbau, kambing, domba, kuda, anjing, babi, dan burung onta. Kejadian luar biasa (KLB) antraks pada jenis unggas dilaporkan pernah terjadi tahun 1999 dengan kematian 254 burung onta di Kabupaten Purwakarta (Hardjoutomo dkk 2002 dalam Martindah, 2017). Provinsi Jawa Timur sebagai gudang sapi wajib melakukan surveillans secara berkesinambungan agar terbebas dari kemungkinan terjadinya wabah penyakit menular berbahaya tersebut.

Provinsi Jawa Timur sebagai gudang ternak ruminansia dan unggas didukung oleh keberadaan populasi sapi potong mencapai 4,5 juta ekor; menempatkan Jawa Timur dalam posisi teratas populasi sapi potong di Indonesia; dan sapi perah 275.675 ekor pada tahun 2017. Selain itu Provinsi Jawa Timur 
merupakan penopang utama keberhasilan Upaya Khusus Sapi Induk Wajib Bunting (Upsus Siwab) dengan capaian target IB 1,7 juta dosis dengan tingkat kebuntinga $76 \%$ dan pedet lahir 772.000 ekor (disnak. jatimprov.go.id).

Populasi sapi tersebar di seluruh wilayah kabupaten dan kota; dimiliki oleh peternak dengan jumlah yang sangat bervariasi dari satu sampai puluhan dan bahkan ratusan ekor. Pacitan dan Blitar termasuk gudang ternak utamanya sapi dan ayam. Pencegahan dan pengendalian antraks di daerah endemik wajib dilakukan dengan cara vaksinasi secara bertahap (Murwani dkk, 2017; Ruhiat dkk, 2018). Disinfeksidilakukan dengan penyemprotan formalin ke tempat-tempat yang dicurigai terkontaminasi spora bakteri antraksis seperti RPH, dan tanah untuk mengubur sapi yang mati karena antraks, kandang dan peralatan kandang. Jika ada manusia yang meninggal karena antraks harus dihindari kulit kontak dengan darah atau cairan tubuh yang terkontaminasi. Manifestasi klinis penyakit antraks umumnya tergantung dari rute masuknya spora; yaitu: (1) Cutaneous anthracis, spora masuk ke dalam tubuh hospes melalui kulit yang luka; (2) Gastrointestinal anthracis, spora masuk lewat daging hewan yang terinfeksi ditandai dengan demam, diare berdarah, muntah, dan nyeri abdomen; (3) Inhalation anthracis terjadi jika spora yang tertelan menuju ke saluran pernafasan (Murwani dkk, 2017).

Terkait dengan pencegahan penyakit menular berbahaya tersebut segenap pemangku kepentingan dan masyarakat luas harus saling peduli dan jika menjumpai gejala-gejalanya harus segera menghubungi dokter dan petugas kesehatan yang berwenang. Sebagai tindakan preventif, vaksinasi antraks diberlakukan

10 Provinsi dengan Populasi Sapi Potong Terbesar 2017

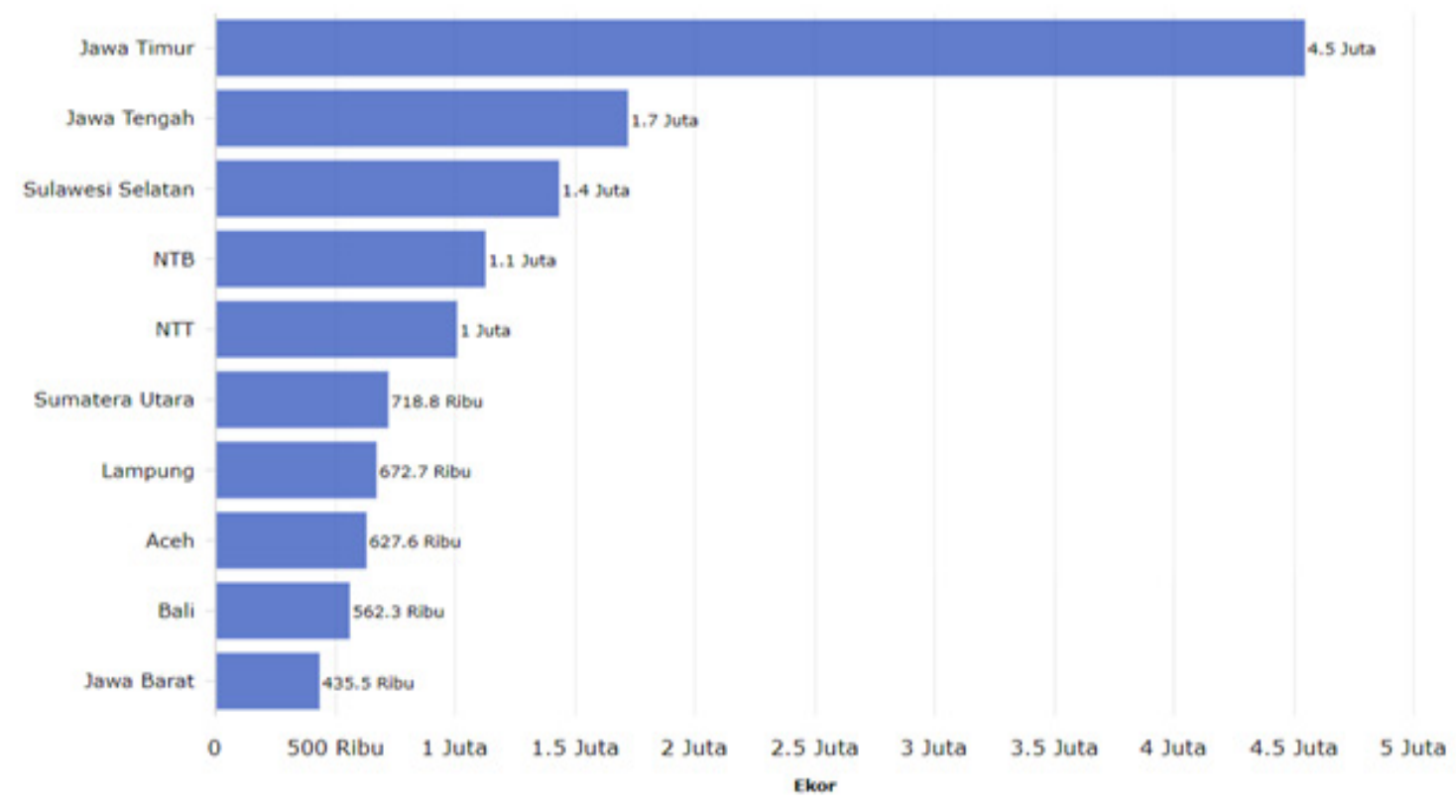

\section{Gambar 8}

Provinsi dengan Populasi Sapi Potong terbanyak Tahun 2017

Sumber: https://databoks.katadata.co.id/datapublish/2018/02/15/jawa-timur-provinsidengan-populasi-sapi-potong-terbesar 
pada manusia dan hewan. Vaksinasi pada ternak sapi perlu dilakukan secara teratur; dan jika terdapat sapi yang menunjukkan gejala terserang antraks harus segera dikarantina dan sesegera mungkin diobati dengan penicillin dosis tinggi (Rianto dan Purbowati, 2010).Beberapa kejadian gangguan penyakit yang telah dilaporkan pada kurun waktu 2016-2017dan residu obat pada Tabel 1.

Selanjutnya, PHMS kedua yang ditemukan adalah Brucellosis (Jawa: keluron menular) yang ditemukan pada sapi perah di Banyuwangi (Dewi dkk, 2017). Brucellosis merupakan penyakit infeksi zoonosis terutama pada sapi,

Tabel 1. Beberapa Kejadian Penyakit Ternak dan Temuan Residu Obat pada Daging di Jawa Timur

\begin{tabular}{|c|c|c|c|c|c|}
\hline No & Jenis Penyakit & Waktu & Lokasi & Keterangan & Sumber Data \\
\hline 1 & Leptospirosis & Febr 2017 & Magetan & $\begin{array}{l}\text { KLB - satu orang mening- } \\
\text { gal }\end{array}$ & Sanyasi, 2018 \\
\hline 2 & Brucellosis & Desb 2017 & Banyuwangi & $\begin{array}{l}\text { Sapi perah } 3 \% \text { dari } \pm 75 \\
\text { kasus }\end{array}$ & $\begin{array}{l}\text { Dewi dkk, } \\
2017\end{array}$ \\
\hline 3 & Antraks & Agst 2016 & Pacitan & $\begin{array}{l}\text { Sapi terinfeksi Bacillus } \\
\text { anthracis (suspect An- } \\
\text { thrax) melalui kontaminasi } \\
\text { spora pada lingkungan. } \\
\text { Cuaca yang tidak menentu } \\
\text { disertai dengan hujan } \\
\text { selama dua (2) hari didaerah } \\
\text { kasus, dapat juga menjadi } \\
\text { faktor penyebab penularan } \\
\text { penyakit ini. }\end{array}$ & $\begin{array}{l}\text { Indah dkk } \\
2017\end{array}$ \\
\hline 4 & $\begin{array}{l}\text { Infeksi Rhinotra- } \\
\text { cheitis }\end{array}$ & Pebr 2017 & $\begin{array}{l}\text { Probolinggo, } \\
\text { Pasuruan, } \\
\text { Tuban }\end{array}$ & $\begin{array}{l}\text { Sapi, rata-rata kejadian } \\
0,220-0,230 \text { namun perlu } \\
\text { waspada agar tidak menye- } \\
\text { bar. }\end{array}$ & $\begin{array}{l}\text { BB Veteriner } \\
\text { Wates, } 2017\end{array}$ \\
\hline 5 & Paratubercullosis & $\begin{array}{l}\text { Jan }- \text { Pebr } \\
2017\end{array}$ & $\begin{array}{l}\text { Probolinggo, } \\
\text { Malang, Pas- } \\
\text { uruan, Tuban }\end{array}$ & Sapi, rata-rata $0,003-0,229$ & $\begin{array}{l}\text { BB Veteriner } \\
\text { Wates, } 2017\end{array}$ \\
\hline 6 & $\begin{array}{l}\text { Nematodosis dan } \\
\text { Fascioliasis (cac- } \\
\text { ing hati) }\end{array}$ & Pebr 2017 & $\begin{array}{l}\text { Probolinggo, } \\
\text { Malang, } \\
\text { Pasuruan }\end{array}$ & $\begin{array}{l}\text { Sapi, total kejadian } 29,16 \% \\
\text { untuk Nematodosis dan } \\
34,74 \% \text { Fasciolosis }\end{array}$ & $\begin{array}{l}\text { BB Veteriner } \\
\text { Wates, } 2017\end{array}$ \\
\hline 7 & $\begin{array}{l}\text { Residu Gol Tetra- } \\
\text { cyclin }\end{array}$ & Pebr 2017 & $\begin{array}{l}\text { Lamongan, } \\
\text { Tuban }\end{array}$ & Sapi, $22,22 \%$ & $\begin{array}{l}\text { BB Veteriner } \\
\text { Wates, } 2017\end{array}$ \\
\hline 8 & $\begin{array}{l}\text { Residu Gol Ami- } \\
\text { noglikosida }\end{array}$ & Pebr 2017 & $\begin{array}{l}\text { Lamongan, } \\
\text { Tuban }\end{array}$ & Ayam, $43,14 \%$ & $\begin{array}{l}\text { BB Veteriner } \\
\text { Wates, } 2017\end{array}$ \\
\hline
\end{tabular}

dan bison. Brucellosis pada sapi terutama disebabkan oleh bakteri Brucella abortus. Penyakit ini dapat menyebar dengan cepat dan menyebabkan aborsi pada sapisapi yang tidak divaksinasi dan bersifat endemik. Penyebaran alami terjadi melalui ingesti bakteri. Bakteri dalam jumlah besar ditemukan pada fetus yang aborsi, membran fetal, leleran uterin. Brucella sp mampu hidup dari fetus dan feses yang berada dalam lingkungan dingin lebih dari 2 bulan; dan paparan matahari langsung dapat membunuh Brucella sp dalam beberapa jam. Transmisi penyakit ke manusia biasanya melalui kontak langsung dengan material terkontaminasi bakteri atau tidak langsung melalui ingesti produk

Sumber: Data Primer Diolah, 2018 
makanan dan per inhalasi. Kontaminasi dari susu mentah atau keju dari susu mentah merupakan sumber infeksi pada manusia; utamanya fresh cheese dari susu kambing dan domba ( Murwani dkk, 2017). Sapi bunting yang mengalami serangan brucellosis akan mengalami abortus pada 6-9 bulan kebuntingan. Sapi jantan yang terserang brucellosis skrotumnya akan membengkak berwarna merah dan dapat menyebabkan steril (Blakely dan Bade, 1992). Pencegahan brucellosis yang efektif adalah melakukan vaksinasi strain 19 usia 3-7 bulan. Sapi yang sakit diberi antiseptik dan antibiotik berupa kombinasi penisilin dan streptomisin, meritin, atau oestrilan yang diberikan intrauterina (Rianto dan Purbowati, 2010).

Penyakit Infectious Bovine Rhinotracheitis (IBR) pada sapi dilaporkan terjadi pada beberapa lokasi yaitu Probolinggo, Pasuruan, dan Tuban oleh tim Balai Besar Veteriner Wates tahun 2017. Penyebab IBR adalah virus herpes dengan tingkat kematian prenatal dan neonatal cukup tinggi. Penularan penyakit IBR dapat melalui semen terinfeksi, air, pakan, kontak langsung dengan cairan lendir mukosa hewan terinfeksi, dan melalui lingkungan tercemar (Rianto dan Purbowati, 2010). Walau kejadian serangan IBR jumlahnya relatif kecil namun perlu segera ditangani secara seksama. IBR merupakan penyakit pernafasan pada sapi yang secara signifikan merugikan khususnya bagi usaha perbibitan sapi. Kejadian IBR bersifat sangat infeksius mengakibatkan gangguan pernafasan, reproduksi, dan syaraf yang dapat menghambat kinerja pembibitan. Pengendalian penyakit IBR perlu dilakukan pada pusat-pusat perbibitan dan Inseminasi Buatan (IB) serta peternakan sapi rakyat (Adjid dan Saepulloh, 2010). Probolinggo, Pasuruan, dan Tuban termasuk sentra sapi potong utamanya sapi Madura dan sapi Peranakan Ongole (PO) yang merupakan sumber sapi potong atau sapi pedaging.
Penyakit paratuberculosis dilaporkan terjadi di Probolinggo, Malang, Pasuruan, dan Tuban pada tahun 2017. Paratuberculosis adalah penyakit khronik, interitis granulomatous yang infeksius. Pada sapi ditandai dengan gejala diare persisten, terjadi penurunan berat badan secara progresif, lemah, dan dapat menyebabkan kematian (Murwani dkk, 2017).Paratuberculosis disebabkan oleh bakteri Mycobacterium paratuberculosis yang biasanya tidak dapat disembuhkan (Blakely dan Bade, 1992).

Leptospirosis dilaporkan terjadi di Magetan. Magetan selama ini terkenal sebagai pusat sapi kereman dan merupakan sumber sapi pedaging yang sangat potensial. Penyebab leptospirosis adalah 3 strain bakteri, yaitu Leptospira pomona, L grippotyphosa, dan L hardjo. Leptospirosis menyerang ginjal dengan tingkatan bervariasi sehingga menybabkan keguguran, mastitis, suhu badan tinggi, urine berwarna seperti anggur, dan anemia. Pedet yang terserang leptospirosis akan mati; namun sapi tua bisa disembuhkan. Leptospirosis dapat menular pada ternak dan manusia; dan air merupakan media penyebaran utama (Blakely dan Bade, 1992).

Berbagai gangguan penyakit ternak yang terjadi di Jawa Timur telah dapat tertangani dengan baik. Hal tersebut didukung oleh keberadaan UPT Laboratorium Kesehatan Hewan di Malang dan UPT Laboratorium Kesehatan Hewan Tuban. Kedua UPT tersebut memiliki tugas yang sama yaitu melaksanakan surveillance, monitoring dan evaluasi penyakit hewan/ternak secara aktif, dan pasif, secara aktif rutin dan terjadwal untuk mendapatkan diagnosa baik klinis dan laboratoris guna pemetaan penyakit hewan di wilayah kerja masing-masing. Namun demikian kewaspadaan peternak tetap perlu ditingkatkan terhadap berbagai kejadian penyakit yang bisa timbul setiap 
Tabel 2. Penyakit yang tergolong dalam PHMS

\begin{tabular}{|c|c|c|}
\hline No. & Jenis Penyakit & Keterangan \\
\hline 1 & Anthrax & $\begin{array}{l}\text { Menyerang hewan herbivora, babi, anjing, dan burung } \\
\text { onta. }\end{array}$ \\
\hline 2 & Rabies & Menyerang semua mamalia berdarah panas \\
\hline 3 & Penyakit mulut dan kuku & Menyerang hewan berkuku genap \\
\hline 4 & Bovine Spongioform Encephalopathy & Menyerang ruminansia dan bersifat zoonosis \\
\hline 5 & Salmonellosis & Menyerang hewan \& manusia \\
\hline 6 & Rift Vallay Fever & Menyerang sapi \& domba \\
\hline 7 & Brucellosis (Brucella abortus) & Menyerang sapi \& kerbau \\
\hline 8 & Avian Influenza & Menyerang unggas \& mamalia \\
\hline 9 & $\begin{array}{l}\text { Porcine Reproductive \& Respiratory } \\
\text { Syndrome }\end{array}$ & Menyerang babi \& bersifat immunosupresif \\
\hline 10 & Helminthiasis & Menyerang ruminansia \\
\hline 11 & Haemorragic septicaemia & Menyerang ruminansia, kuda, babi \\
\hline 12 & Nipah Virus Encephalitis & Menyerang babi \& manusia \\
\hline 13 & Infectious Bovine Rhinotracheitis & Menyerang sapi \& kerbau \\
\hline 14 & Bovine Tuberculosis & Menyerang sapi, ternak liar \& manusia \\
\hline 15 & Leptospirosis & Menyerang hewan \& manusia \\
\hline 16 & Brucella Suis pada babi & Menyerang babi \& manusia \\
\hline 17 & Penyakit Jembrana & Meyerang sapi Bali \\
\hline 18 & Surra & Meyerang semua hewan \\
\hline 19 & Paratuberculosis & Menyerang semua hewan $\&$ manusia \\
\hline 20 & Toxoplasmosis & Menyerang semua hewan \\
\hline 21 & Classical Swine Fever & Menyerang babi \\
\hline 22 & Swine Influenza Novel (H1N1) & Menyerang manusia \\
\hline 23 & Campylobacteriosis & Menyerang semua hewan \\
\hline 24 & Cysticercosis & Menyerang babi, sapi, manusia \\
\hline 25 & Q Fever & Menyerang ruminansia \\
\hline
\end{tabular}

Sumber: http://www.litbang.pertanian.go.id/download/one/407/file/BOOKLET-PHMS.pdf

saat.Penerapan kewaspadaan dini oleh kontak langsung dengan penderita, petugas kesehatan hewan, dokter hewan, melalui makanan yang dikonsumsi, atau dan otoritas veteriner dilakukan melalui melalui udara yang terhirup dan/atau pemeriksaan dan pengujian sampel dan kontak langsung dengan hewan yang sakit, atau spesimen secara cepat, respon cepat, terinfeksi atau mati. Selama kurun waktu dan membangun kesadaran masyarakat 2016-2017 dilaporkan terdapat lima(5)jenis sesuai dengan pedoman kesiagaaan darurat kejadian PHMS; yaitu antraks, brucellosis, veteriner. Beberapa jenis penyakit PHMS IBR, leptospirosis, dan paratubercullosis; adalah pada Tabel 2 .

\section{Kesimpulan}

Dari 25 jenis penyakit hewan menular strategis yang teridentifikasi, terdapat beberapa jenis diantaranya yang dapat menimbulkan bahaya bagi kesehatan manusia yang terpapar baik melalui dan dua (2) jenis kejadian penyakit parasiter. Selain itu terdapat residu dua jenis obat golongan Tetracyclin pada daging sapi dan Aminoglikosida pada daging ayam. Cara mencegah dan menanggulangi berbagai penyakit agar produksi pangan asal ternak tidak terganggu adalah senantiasa menggunakan bibit unggul 
bersertifikat (kalau ada) serta menerapkan cara beternak yang baik, menggukan pakan yang sehat, dan menerapkan biosekuriti secara ketat. Penyakit pada ternak dapat menular dan membahayakan kesehatan manusia sehingga dalam rangkaian proses produksi perlu dijalankan dengan senantiasa menerapkan cara beternak yang baik. Ternak yang sakit tidak boleh dipotong apalagi dikonsumsi karena bisa menjadi agen penularan penyakit yang bisa berdampak meluas secara sosiologis dan ekomonis. Ternak sakit harus dilaporkan pada petugas kesehatan hewan secara dini; tidak boleh ditunda dan dibiarkan merana. Peternak wajib dan harus bersahabat baik dengan petugas kesehatan hewan serta berkonsultasi menjaga agar seluruh ternak yang dibudidayakan terkontrol kesehatannya. Kemudahan komunikasi menggunakan hanphone dan internet membantu peternak dan petugas kesehatan ternak untuk bersama membudidayakan dan meningkatkan produksi pangan sumber protein yang sehat.

\section{Daftar Pustaka}

Adarma, T. (2016). Awas, Banjir Bawa Bibit Penyakit Bagi Hewan Ternak. http://beritajatim.com/ peristiwa/260798/awas,_banjir_ bawa_bibit_penyakit_bagi_ hewan_ternak.html. Diakses pada 29 Maret 2016.

Adjit, R. M. A dan Saepulloh, M. (2010). Penyakit Infectious Bovine Rhinotracheitis pada Sapi di Indonesia dan Strategi Pengendaliannya. Wartazoa, 20(1), 1-11.

Badan Standarisasi Nasional (BSN). SNI ISO 22000:2005. Sistem manajemen Keamanan Pangan - Persyaratan untuk Organisasi dalam Rantai Pangan.
Balai Besar Penelitian Veteriner. (2012). Informasi dan Diskripsi Singkat Penyakit Hewan Menular Strategis (PHMS). Jakarta: Balitbang Pertanian, 14h. http://www. litbang.pertanian.go.id/download/ one/407/file/BOOKLET-PHMS. pdf. Diakses pada 2018.

Bahri, S., Indraningsih, W. R., Murdiati, T. B., dan Maryam R. (2002). Keamanan Pangan Asal Ternak : Suatu Tuntutan di Era Perdagangan Bebas. Wartazoa, 12(2), 47-64.

Bahri, S., Sani, Y., dan Indraningsih, (2006). Beberapa Faktor yang Mempengaruhi Keamanan Pangan Asal Ternak di Indonesia. Jakarta: Wartazoa, 16(1), 1-13.

Blakely, J., dan Bade, D. H. (1992). Ilmu Peternakan. Edisi Keempat. Terjemahan. Yogyakarta: Gajah Mada University Press.

Daryanto, A. (2017). Praktik Suap dan Kuota Impor Daging Sapi. Jakarta: Trobos,

Dirjen Peternakan. (2017). Situasi Kejadian Ai Pada Unggas Kondisi Sampai Dengan Maret 2017. http://ditjennak.pertanian.go.id/ situasi-kejadian-avian-influenzaai-pada-unggas-kondisi-s-d-31maret-2017. Diunduh 17 Agustus 2017.

Murwani, S., Qosimah, D., dan Amri, I. A. (2017). Penyakit Bakterial Pada Ternak Hewan Besar dan Unggas. Malang: UB Press.

Natalia, L. (2000). Manifestasi Veseral Penyakit Radang Paha pada Hewan. JITV, 5(1), 276-281. 
Nugraheni, M. (2013). Pengetahuan Bahan Pangan Hewani. Yogyakarta: Graha Ilmu.

Martindah, E. (2017). Faktor Risiko, Sikap, dan Pengetahuan Masyarakat Peternak dalam Pengendalian Penyakit Antraks. Jakarta: Wartazoa, 27(3), 135-144.

Rianto, E., dan Purbowati, E. (2010). Panduan Lengkap Sapi Potong. Depok: Penebar Swadaya.

Ruhiat, E., Suhardi, H. A., dan Mariyono. (2018). Gambaran Status Penyakit

Supar dan Ariyanti, T. (2005). Keamanan Pangan Produk Peternakan Ditinjau dari Aspek Penyakit. Wartazoa,15(4), 187-2005.

Talib, C., Inounu, I., dan Bamualim, A. (2007). Restrukturisasi Peternakan di Indonesia. Analisis Kebijakan Pertanian, 5(1), 1-14.

Undang-Undang Nomor 18 Tahun 2012 Tentang Pangan. Lembaran Negara Republik Indonesia Tahun 2012 Nomor 227.
Undang-Undang Nomor 41 Tahun 2014 Tentang Perubahan Atas UndangUndang Nomor 18 Tahun 2009 Tentang Peternakan dan Kesehatan Hewan. Lembaran Negara Republik Indonesia Tahun 2014 Nomor 338

Wheindrata, H. S. (2015). Flu Burung. Kenali, Cegah dan Obati Sedini Mungkin. Yogyakarta: Lily Publisher 